\title{
Reinforcing pop sheets with textile fabrics
}

\begin{abstract}
POP sheets used for making false ceiling for the purpose of decoration or for technical reason. In the current study an attempt has been made to investigate effect of different Textile Fabrics on commercial plaster of paris ( $\mathrm{PoP})$ in a view to investigate the mechanical behavior of resultant PoP Sheets. Addition of small closely spaced and uniformly distributed fabric structure makes bond with PoP \& uniform structure can help to act as crack arresters. It also can improve its mechanical strength, durability $\&$ safety concerns. As a result of this sort of uniform fabric structure the resultant plaster becomes little flexible from inside along with high strength provided by the outer materials.

The ability of the Textile Reinforced PoP Sheets to retain strength at the onset of matrix cracking has been analyzed; the Bending Stress results of Textile Reinforced PoP were compared with Plain PoP. It shows that Textile Reinforced PoP sheets are better in mechanical behavior in comparison to Plain PoP Sheets.
\end{abstract}

Keywords: composites, fibres, gypsum, plaster of paris, mechanical properties, reinforcement
Volume 2 Issue 2 - 2017

\section{Ashwin Thakkar,' Laxmi Chaudhary Mehra Department of Textile Technology, LD College of Engineering,} India

Correspondence: Ashwin Thakkar, Department of Textile Technology, LD College of Engineering, Ahmadabad, India, Tel 98 7923 3838,Email ashwin@Idce.ac.in

Received: February 19, 2017| Published: July 10, 2017

\section{Introduction}

Plaster of Paris or Gypsum powder is basically a sedimentary rock which settled through the evaporation of sea water trapped in lagoons. The Gypsum boards are used extensively for variety of reasons like false ceiling, decoration etc. When used as false ceiling they sometimes pose a serious threat as it is prone to cracking. Major factors for development of cracks are: pressure, temperature, moisture, chemical attacks and ageing. ${ }^{1}$ So there is need to reinforce the Gypsum boards with the help of flexible yet stronger textile material.

As it is known that with reinforcement of textile fibre in concrete materials, novel repair and/or retrofit can be developed which would lead to substantially higher strengths, seismic resistance, ductility, durability than conventional methods. Many studies have shown that glass fibre-reinforced concrete materials possess appreciable toughness values. Here in this work focus is on PoP False ceiling sheets reinforced with different textile fabrics that are woven structured form of textiles. It can be a promising solutions or new way of resolving cracking problems \& improving mechanical properties with high performance textile fabric reinforcement. ${ }^{1}$

Depending upon the technique, temperature, etc. different types of Plaster of Paris can be produced. Three forms of the Plaster of Paris are Table ITextile Specifications used for Reinforcement of PoP sheets identified, namely (i) Alpha, (ii) Beta \& (iii) Phospho-Gypsum (PoP). Alpha Plaster is the best quality \& is used in Medical applications where as Beta plaster is used in high grade ceramic industries. Alpha plaster has found superior strength. ${ }^{2}$ The Building boards generally used as partitioning, paneling, cladding and false ceiling are mainly made from industrial wastes such as Phospho-Gypsum (Plaster of Paris). ${ }^{2}$

\section{Materials used for textile reinforced pop boards}

Gypsum plaster powder: ${ }^{3}$ Building boards generally used as partitioning, paneling, cladding and false ceiling shall be made from industrial wastes such as phospho-gypsum. ${ }^{3}$

Water: Potable water is generally considered satisfactory for mixing plaster. (Water-plaster ratio of 0.5 to 0.6 ).

Oil and greases: The oil and greases used in the preparation of benches and moulds for casting shall be such that it will leave the plaster surface of the product clean and unstained.

Fabric specimens: The reinforcing fabric samples were procured from different suppliers with varied specifications. The detailed specifications $\&$ physical properties are as given in Table 1 .

\begin{tabular}{|c|c|c|c|c|c|c|c|c|c|c|c|}
\hline $\begin{array}{l}\text { S. } \\
\text { No }\end{array}$ & $\begin{array}{l}\text { Pop Sheets } \\
\text { with \& } \\
\text { Without } \\
\text { Textile } \\
\text { Reinforcement }\end{array}$ & $\begin{array}{l}\text { Fibre } \\
\text { Composition }\end{array}$ & $\begin{array}{l}\text { Weight } \\
\left(\mathrm{g} / \mathrm{m}^{2}\right)\end{array}$ & $\begin{array}{l}\text { Warp } \\
\text { count } \\
\text { (tex) }\end{array}$ & $\begin{array}{l}\text { Weft } \\
\text { count } \\
\text { (tex) }\end{array}$ & $\begin{array}{l}\text { Fabric } \\
\text { weave }\end{array}$ & Supplier & $\begin{array}{l}\text { Ends per } \\
\text { Inch }\end{array}$ & $\begin{array}{l}\text { Pick per } \\
\text { Inch }\end{array}$ & $\begin{array}{l}\text { Max. } \\
\text { Load } \\
\text { (kgf) }\end{array}$ & $\begin{array}{l}\text { Extension } \\
(\mathrm{mm})\end{array}$ \\
\hline & & & & & & & & $\begin{array}{l}\text { \#ISO } \\
4602\end{array}$ & $\begin{array}{l}\text { \#ISO } \\
4602\end{array}$ & $\begin{array}{l}\text { \#ASTM } \\
\text { D5034 }\end{array}$ & $\begin{array}{l}\text { \#ASTM } \\
\text { D5034 }\end{array}$ \\
\hline I & $\begin{array}{l}\text { PLAIN PoP } \\
\text { Board (W/o } \\
\text { Textile Material) }\end{array}$ & Nil & $\sim$ & $\sim$ & $\sim$ & $\sim$ & $\sim$ & $\sim$ & $\sim$ & $\sim$ & $\sim$ \\
\hline 2 & Synthetic Grid & $\begin{array}{l}85 \% \\
\text { E-Glass }+15 \% \\
\text { PP }\end{array}$ & 500 & 400 & 400 & Plain & Mill I & 8 & 8 & 200 & 7.2 \\
\hline
\end{tabular}


Table Continued.

\begin{tabular}{|c|c|c|c|c|c|c|c|c|c|c|c|}
\hline $\begin{array}{l}\text { S. } \\
\text { No }\end{array}$ & $\begin{array}{l}\text { Pop Sheets } \\
\text { with \& } \\
\text { Without } \\
\text { Textile } \\
\text { Reinforcement }\end{array}$ & $\begin{array}{l}\text { Fibre } \\
\text { Composition }\end{array}$ & $\begin{array}{l}\text { Weight } \\
\left(\mathrm{g} / \mathrm{m}^{2}\right)\end{array}$ & $\begin{array}{l}\text { Warp } \\
\text { count } \\
\text { (tex) }\end{array}$ & $\begin{array}{l}\text { Weft } \\
\text { count } \\
\text { (tex) }\end{array}$ & $\begin{array}{l}\text { Fabric } \\
\text { weave }\end{array}$ & Supplier & $\begin{array}{l}\text { Ends per } \\
\text { Inch }\end{array}$ & $\begin{array}{l}\text { Pick per } \\
\text { Inch }\end{array}$ & $\begin{array}{l}\text { Max. } \\
\text { Load } \\
(\text { kgf) }\end{array}$ & $\begin{array}{l}\text { Extension } \\
(\mathrm{mm})\end{array}$ \\
\hline 3 & Glass 1200 Tex & $100 \%$ E Glass & 610 & 1200 & 1200 & Plain & Mill 2 & 25 & 25.8 & 195.5 & 6.1 \\
\hline 4 & Glass 600 Tex & $100 \%$ E Glass & 402 & 600 & 600 & Plain & Mill 2 & 35.4 & 31.5 & 151 & 4.6 \\
\hline 5 & Glass 300 Tex & $100 \%$ E Glass & 360 & 300 & 300 & Plain & Mill 3 & 63 & 55.6 & 164 & 5.6 \\
\hline 6 & Glass 4 Layer & $100 \%$ E Glass & 614 & 300 & 300 & 4 Layer & Mill 3 & $\begin{array}{l}\text { I,2,3,4th } \\
\text { Layer: } 30 \mathrm{I}, \\
3,4,301 \\
\left(\mathrm{~g} / \mathrm{m}^{2}\right)\end{array}$ & $\begin{array}{l}\text { I,2,3,4th } \\
\text { Layer: } \\
30 \mathrm{I}, 3,4 \\
30 \mathrm{I}(\mathrm{g} / \\
\left.\mathrm{m}^{2}\right)\end{array}$ & 6.5 & 50.3 \\
\hline 7 & $\begin{array}{l}\text { Polypropylene } \\
\text { Grid }\end{array}$ & $100 \%$ PP & 485 & 400 & 400 & Plain & Mill I & 9 & 9 & 150 & 6.5 \\
\hline 8 & HDPE Agronet & $100 \%$ HDPE & 400 & 200 & 200 & Plain & Mill I & 15 & 15 & 170 & 8 \\
\hline 9 & NYLON Net & $100 \%$ Nylon & 350 & 200 & 200 & Plain & Mill I & 12 & 12 & 140 & 7.5 \\
\hline
\end{tabular}

\section{Method of preparation}

The Gypsum is heated to remove about $3 / 4$ of water and the process is called calcinations. This results in calcium sulfate hemihydrates of popularly known as Plaster of Paris (PoP). It is cooled immediately and stored in the powder form. During use water is added to rehydrate the powder and sets in to the mould during drying. ${ }^{3}$

The Process steps of preparation of Textile Reinforced PoP Sheets are as follows:

a. A wooden frame $1 \mathrm{~mm}$ thinner than the thickness of the board required was laid over plain casting table having smooth trowelled surface or polished stone surface.

b. The table was coated with a thin layer of oil to prevent plaster board sticking to the surface.

c. Gypsum plaster was gauged to an even consistency free from lumps. This was spread evenly to cover the entire surface of the casting table within the mould to an even thickness of $6 \mathrm{~mm}$ and allowed to set partially.

d. The textile reinforcement fabric specimen was laid evenly over the surface.

e. The requisite amount of body plaster was then poured over the fabric, and the fabric was pressed and rolled down until it was thoroughly incorporated in the body plaster.

f. The fabric was turned into the board to strengthen the edges and the whole board shall then be ruled to an even thickness.

g. When the sheet hardened sufficiently, it was lifted and placed in racks or at separate place to dry.

h. This way all pop resultant sheets were prepared. The size of the board prepared was kept as: Length $\times$ Width $\times$ Thickness $=$ $450 \times 300 \times 12 \mathrm{~mm}$

\section{Details of the test parameters}

Tests

i. Visual inspection: All boards shall be sound, free from cracks, broken edges and such other imperfections that would render them unfit for use.

ii. Transverse bending strength: The transverse bending strength when tested in accordance with IS 2542(Part II). The test was carried out on UTM (Tinius Olsen Model H10KS). Figure 1 shows the arrangement for 3-point bending test as per IS 2542 (Part II). ${ }^{4}$

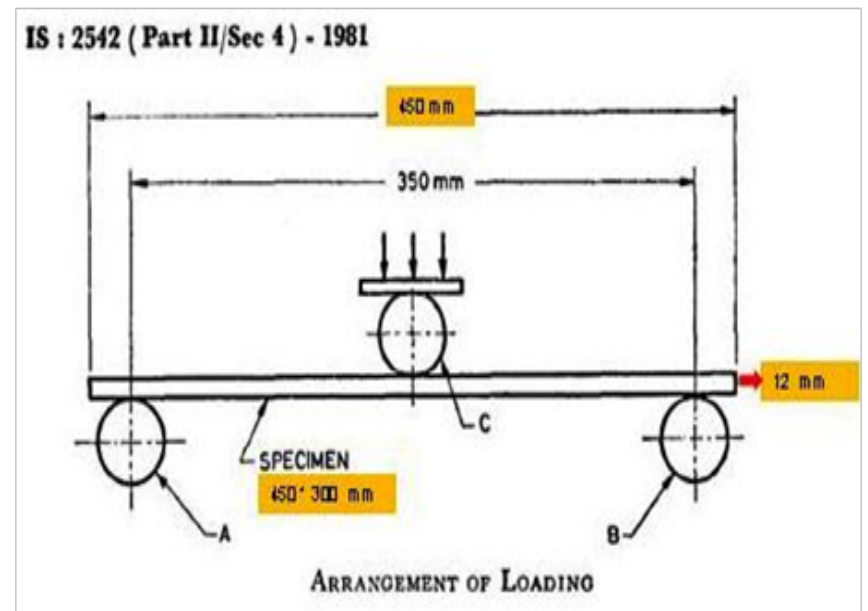

Figure I Three Point-Bending strength Testing Arrangements.

\section{Results and discussions}

After drying for 4 days at room temperature, the smooth specimens of dimensions $450 \times 300 \times 12 \mathrm{~mm}$ were loaded for three point bending test at a crosshead displacement rate of $5 \mathrm{~mm} / \mathrm{min}$, on Tinius Olsen UTM testing machine equipped with a $10 \mathrm{kN}$ load cell and tested as per IS 2542, as shown in Figure 2.

Load (P) in N \& Extension (E) in \% were recorded at the point of first damage in terms of prominent crack. Maximum Moment $(\mathrm{M})$ in N.mm \& Section Modulus $(Z)$ in mm was calculated as per equations given below:

$$
M=P / 2 * 150
$$




$$
Z=(b * d)^{2} / 6
$$

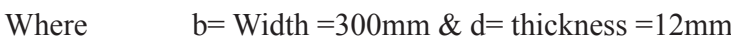

Finally bending stress (f) in N. $\mathrm{mm}^{2}$ was calculated as per following equation:

$$
f=M / Z
$$

Also difference observed in mode of cracking was noted. For each specimen the recorded Load \& Extension values \& obtained Bending Stress are mentioned in Table 2. Please note, if the specimen in the transverse strength test fails at its centre, the transverse strength is equal to the flexural strength.

Please note that in case of Plain PoP Sheets, a sudden \& very sharp crack observed upon loading as the critical point reached in Figure 3a

Whereas all Textile Reinforced PoP sheets with Synthetic Grid, Glass 1200 Tex, PP Grid, HDPE Agronet \& Nylon Net, could make good bonding with PoP \& even at comparatively higher loading Table 2 Average Bending Stress values of Plain \& Textile Reinforced Pop no breakage occurred and only minor hair line crack observed in Figure 3b. It was observed that the open structure of fabric helped in achieving good bonding. On the onset of the first damage within the composites, the load is transferred onto the fabrics in the plane of the crack, which will be elastically stretched. We can say that elasticity property of Textile fabric can help to absorb sudden jerks.

The other sheets reinforced with Glass 600 Tex, Glass 300 Tex, and Glass 4 Layer Failed. One possible reason for the same can be very dense construction of fabric which could not make good bonding with Plaster layers \& Delaminated at loading. However sheets are not broken but failed as Delaminated in Figure 3c.

Our understanding can be clearer from below graphs. Figures 4-7 explain that all Textile Reinforced PoP sheet could bare more load. Synthetic grid, Open structured net gave the best results, shown 2.4 times i.e. $140 \%$ Higher Bending stress in comparison to Plain PoP. However cost point of view PP Grid is economical \& gives 30\% higher Bending stress than Plain PoP. HDPE Agronet \& Nylon net

\begin{tabular}{|c|c|c|c|c|c|c|c|c|c|}
\hline $\begin{array}{l}\text { S. } \\
\text { No }\end{array}$ & $\begin{array}{l}\text { Pop sheets with } \\
\& \text { without textile } \\
\text { reinforcement }\end{array}$ & $\begin{array}{l}\text { Elongation } \\
\mathrm{E}(\%)\end{array}$ & $\begin{array}{l}\text { Load } \\
\mathbf{P}(\mathbf{N})\end{array}$ & $\begin{array}{l}\text { Max. } \\
\text { moment } \\
\text { (M) }\end{array}$ & $\begin{array}{l}\text { Section } \\
\text { modulus(mm) }\end{array}$ & $\begin{array}{l}\text { Bending } \\
\text { stress(N/ } \\
\left.\text { mm }^{2}\right)\end{array}$ & $\begin{array}{l}\text { Mode of } \\
\text { cracking }\end{array}$ & $\begin{array}{l}\text { Result } \\
\text { status }\end{array}$ & $\begin{array}{l}\text { Relative } \\
\text { bending } \\
\text { stress }\end{array}$ \\
\hline
\end{tabular}
also shows $20 \%$ increase in Bending Stress values.

\begin{tabular}{|c|c|c|c|c|c|c|c|c|c|}
\hline I & $\begin{array}{l}\text { Plain (without } \\
\text { reinforcement) }\end{array}$ & 1.19 & 302.34 & 22675.82 & 7200 & 3.15 & $\begin{array}{l}2 \text { Pieces-sharp } \\
\text { cut }\end{array}$ & FAIL & 1 \\
\hline 2 & Synthetic Grid & 12.39 & 725.25 & 54394 & 7200 & 7.55 & $\begin{array}{l}\text { Minor hairline } \\
\text { crack }\end{array}$ & PASS & 2.4 \\
\hline 3 & Glass I200 Tex & 16.45 & 428.7 & 32152.28 & 7200 & 4.47 & $\begin{array}{l}\text { Minor hairline } \\
\text { crack }\end{array}$ & PASS & 1.4 \\
\hline 4 & Glass 600 Tex & 15.46 & 504.63 & 37846.98 & 7200 & 5.26 & Delaminated & FAIL & 1.7 \\
\hline 5 & Glass 300 Tex & 15.81 & 550.34 & 41275.58 & 7200 & 5.73 & Delaminated & FAIL & 1.8 \\
\hline 6 & Glass 4 Layer & 16.41 & 426.54 & 31990.41 & 7200 & 4.44 & Delaminated & FAIL & 1.4 \\
\hline 7 & Polypropylene Grid & 17.38 & 397.6 & 29819.95 & 7200 & 4.14 & $\begin{array}{l}\text { Minor hairline } \\
\text { crack }\end{array}$ & PASS & 1.3 \\
\hline 8 & HDPE Agronet & 19.02 & 358.75 & 26906.38 & 7200 & 3.74 & $\begin{array}{l}\text { Minor hairline } \\
\text { crack }\end{array}$ & PASS & 1.2 \\
\hline 9 & NYLON Net & 14.08 & 374.64 & 28098.29 & 7200 & 3.9 & $\begin{array}{l}\text { Minor hairline } \\
\text { crack }\end{array}$ & PASS & 1.2 \\
\hline
\end{tabular}

(N.mm ) 


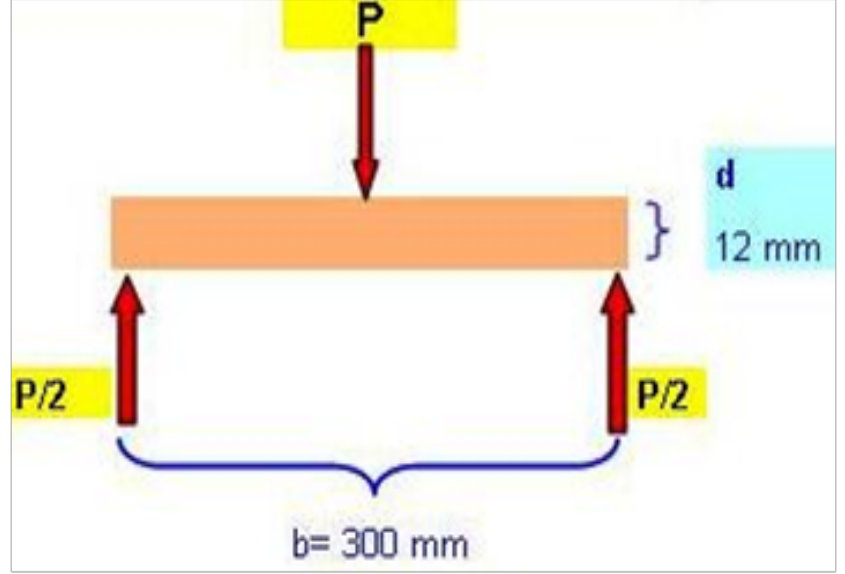

Figure 2 Load calculations.

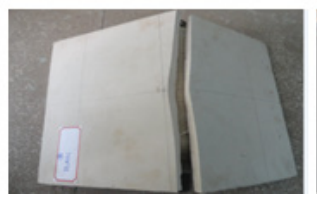

(a)

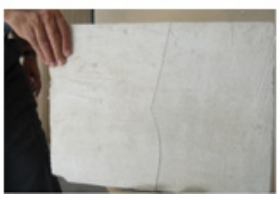

(b)

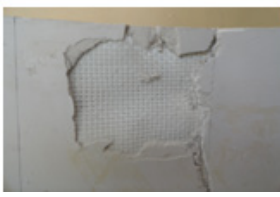

(c)
Figure 3 Plain pop Sheets.

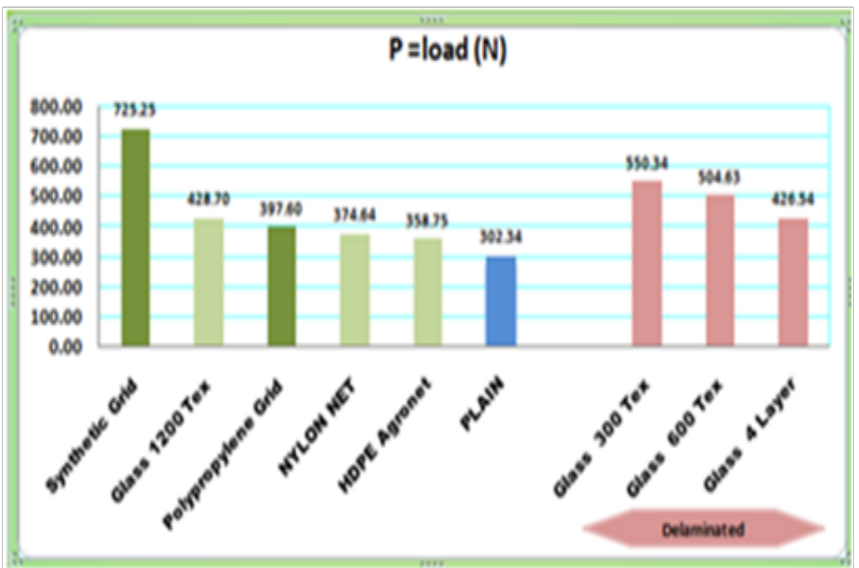

Figure 4 Sheets under loading (Load in N).

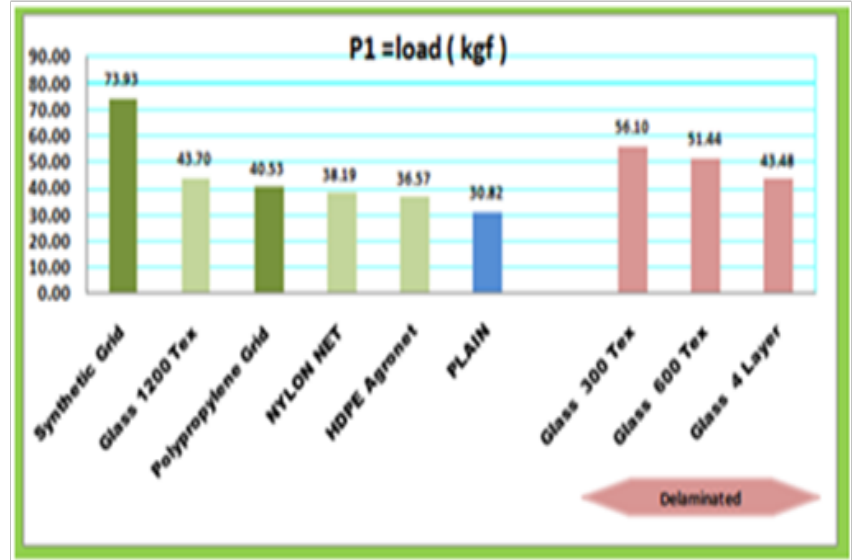

Figure 5 Sheets under loading (Load in kgf).

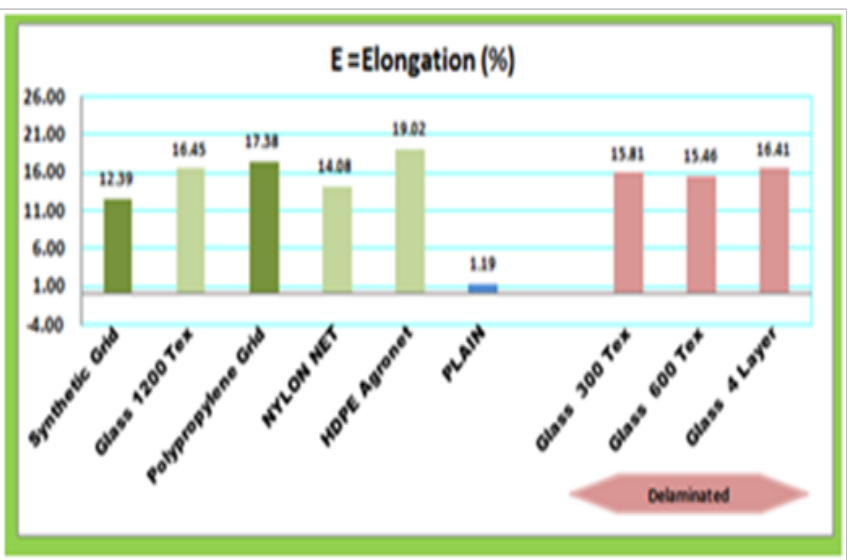

Figure 6 Elongation \%.

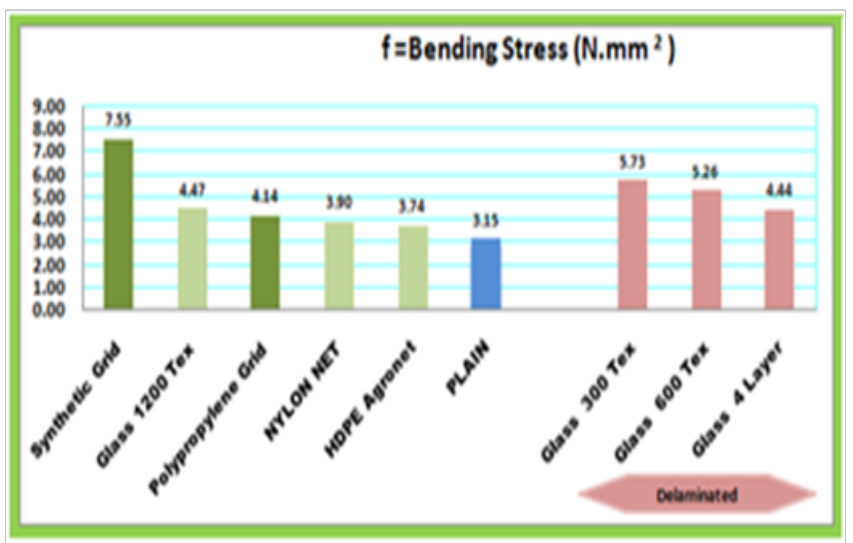

Figure 7 Bending stress [N.mm²].

\section{Summary}

The cost of civil infrastructure constitutes a major portion of the national wealth. Its rapid deterioration has thus created an urgent need for the development of novel, long-lasting and safe methods for repair, retrofit and new construction.

a. A promising new way of resolving this problem is to selectively use advanced composites, such as High-Performance Glass fabric Reinforced PoP for false ceiling. Synthetic Grid fabric with open structure achieved the best results during the experiment. It did not break but developed just minor hairline crack. Also there was no delamination observed.

b. When tried with PP mesh, similar structure that too gave 1.3times higher strength with minor hairline cracks. PP is economical too. Thus the shear stress at tension cracking decreases.

With Textile Reinforcement, PoP becomes flexible from inner side along with high strength provided by the outer materials. Thus addition of small closely spaced and uniformly distributed fabric which makes inner bond with PoP can act as crack arrester and can improve its strength, sustainability \& safety values.

\section{Acknowledgements}

The authors sincerely thank Principal, LD College of Engineering, and Ahmadabad, India for providing permission to publish the paper. Also thanks are due to Prof. (Dr.) HS Patel, Professor of Applied 
Mechanics Department, LD College of Engineering for providing technical assistance regarding the testing procedures, method and calculations.

\section{Conflict of interest}

Authors have no conflict of interest in composing this manuscript.

\section{References}

1. Eve S, Gomina M, Gmouh A, et al. Micro structural and Mechanical behavior of polyamide fibre-reinforced plaster composites. $J$ European Ceramic Society. 2002;22(13):2269-2275.
2. Alpha High Plaster.

3. Specification for gypsum Building Plaster. 1976. p. 1-18.

4. Transverse Bending Strength. IS: 2542 (Part $1 \&$ 2). 